\title{
GENDER, KITCHEN RESOURCES AND STUDENTS' ACADEMIC PERFORMANCE AND RETENTION IN THERMOCHEMISTRY IN CROSS RIVER STATE, NIGERIA
}

\author{
CECILIA NJA, IROHA KALU AND HOPE NEJI
}

(Received 29, September 2014; Revision Accepted 19, October 2014)

\begin{abstract}
The purpose of the study was to ascertain the interactive effect of gender and teaching with or without kitchen resources on the academic performance and retention of secondary school students in Chemistry in Calabar Education Zone, Cross River State, Nigeria. The sample consisted of 120 students selected by stratified random sampling method. The pretest-posttest control group quasiexperimental research design was adopted in the study. The treatment lasted for a period of six weeks. The data collected with a 60-item multiple choice achievement test instrument were analyzed using $2 \times 2$ ANCOVA. The results indicate that there is no significant difference in the academic performance and retention of male and female students taught thermochemistry with and without kitchen resources.
\end{abstract}

KEY WORDS: Kitchen, Gender, Thermochemistry, Performance, Retention

\section{INTRODUCTION}

Academic achievement of students in science subjects generally and in Chemistry in particular had witnessed a deplorable trend in the past decades. Observations from 2005 to 2010 have consistently revealed poor achievement in Chemistry in senior secondary school certificate examination organized by West African Examination Council (West African Examination Council, 2010). Ekpo (1990) observes that there are two main problems associated with the teaching and learning of science which may account for the poor performance in science at the lower levels of education, namely, the manner of presentation and interest in Science. Several studies (Dahar\&Faize, 2011;Oladejo, Olosund, Ojebisi, \&lsola, 2011; Onasanya\& Omosewo,2011) have indicated that instructional resources favourably influence students' interest and achievement in science. None of the studies have considered kitchen resources. Snodgrass (2001) opines that the kitchen is a familiar reference point in teaching science. The inquiring science teacher will find much information that is relevant and valuable in motivating students.
When students participate in the presented activities, demonstration and discussion of kitchen science, they may perform better in science. Demonstration in the kitchen serves a motivational function which may be termed appetizers or desserts, while more involved activities or laboratory exercises are the main courses.

There has been a gross underrepresentation of girls in the sciences and in the number and contribution of women in Science and Technology career. As noted by Lagoke, Jegede and Oyebanji (1997), the concerns about this under-representation are generally economic (world of work), social (reflecting the gender mix and interaction in the society) and philosophical (relating to the equity and equality). Kitchen resources may possibly motivate and arouse the interest of female students in science and perhaps positively affect their performance. The purpose of the research reported here was therefore to ascertain the extent to which the use of kitchen resources in teaching affect male and female Chemistry students' academic performance and retention in Thermochemistry. Specifically, the research question was: How

Cecilia Nja, Department of Curriculum and Teaching, University of Calabar,Calabar, Nigeria. IrohaKalu, Department of Curriculum and Teaching, University of Calabar,Calabar, Nigeria. Hope Neji, Department of Curriculum and Teaching, University of Calabar,Calabar, Nigeria. 
does teaching with and without kitchen resources affect male and female senior secondary 2 Chemistry students' academic performance in and retention of thermochemistry concepts?

\section{Significance}

In many ways the kitchen can be considered the Chemistry laboratory of the home. Within its confines many complex chemical reactions occur on a daily basis such as the denaturing of proteins, the conversion of starch to sugar and the incorporation of that sugar into favorite recipes.

If the teacher is convinced that hands-on science activities have educational value, the kitchen also might be the place to look at because of the plethora of products and possibilities contained within it confines. Educational experiences of all ages, including middle school students can be developed using kitchen science (Freier \& Anderson, 1996). It could perhaps be concluded that the home particularly the kitchen can hardly be equaled by any unit of the human environment in the provision of experiences for the learning of science and technology. The significance of this study lies in the fact that the findings will provide insights on the extent to which the use or otherwise of kitchen resources in teaching interact with gender to facilitate students' academic achievement and retention in Chemistry, particularly thermochemistry concepts.

\section{Theoretical Background}

Constructivism is a learning theory and epistemology that has influenced much of science education lately. It states that students construct their knowledge of the world through their past experiences. Students do not learn much just by sitting in class listening to the teacher, memorizing repackaged assignments, and spitting out answers. They must talk what they are learning, write about it, relate it to past experiences, and apply it to their daily lives. They must make what they learn part of themselves. Rogers (1969) argues that "much significant learning is acquired by doing" and that learning is facilitated when the student is a responsible participant. Vygotsky's social constructivist theory in Palinscar,2005. States that learning takes place in a social context and that in interaction with others. Students are encouraged to say and do when working with kitchen resources.
Teachers who are concerned with students' emotional, social and academic needs have been found to encourage more students' involvement in lessons.

Active learning offers a paradigm for students learning that differs from the traditional lecture method-based model (Johnson, Roger and Karl, 2006). Differences in provision of learning, and amount of learning are obvious from Edgar-Dale's (1969) cone of learning experience. The cone of learning shows that learners only remember $10 \%$ of what they read, $20 \%$ of what they hear, $30 \%$ of what they see, $50 \%$ of what they hear and see, $70 \%$ of what they say and $90 \%$ of what they say and do. The research was conducted within the theoretical context of social constructivist theory and EdgarDale's cone of learning experience.

Udo (2003) investigated gender influence on achievement and retention of Chemistry concepts among senior secondary 3 students who were taught redox reaction and electrochemistry using corrosion experiments and conventional galvanic cell experiments as instructional models. The result revealed that there was no significant difference between the male and female students' retentions as measured by Chemistry retention test.

Arowoko (2003) in his study on gender and cognitive achievement of male and female was significant and was in favour of males. In a similar vein, a study conducted by Agommoh and Nzewi (2004) on effect of video-taped instruction on Secondary School students' achievement in physics in Umuahia showed that gender was not significant.

Debacker and Nelson (2000) conducted a study to test the interaction effects of gender, class type and ability amongst High school students' retention level. When looking at gender, there was no effect on any of the variables tested, specially the class-type (Physical or Biological science. The researcher proposes that the use of the learning cycle methodology in class may account for the lack of gender differences.

Results of the retention test for boys and girls in the physical textbook group were not statistically significant at the $\propto=0.05$ level. Boy $\bar{x}=6.13$, girls $\bar{x}=7.73 . \mathrm{F}(17)=0.72, \mathrm{t}$ cal $=$ 1.76 at $\mathrm{df}=12.53$ (Kelly, 2008).

Gender differences in examination performance cannot be assumed to be due to inherent biological differences between genders, even if they exist. Lovell and White (1995) notes 
that the theory of innate gender difference in achievement has weak evidence and that in many psychological areas, it is virtually impossible to separate completely the innate from the acquired.

\section{Design and procedure}

The research design was pretest-posttest control group quasi-experimental design with gender as a moderator variable. The retention test was given two weeks after the posttest. The study was carried out in Calabar Education Zone of Cross River State, Nigeria. The sample consisted of 240 Senior Secondary School II Chemistry students from four schools in four Local Government Areas in Calabar Education Zone, selected using the stratified random and purposive sampling methods. There were 120 students each in the experimental and control groups. The experimental group had 67 males and 53 females, while in the control there were
60 males and 60 females. The experimental groups were taught using kitchen resources while the control groups were taught using conventional teaching method without kitchen resources. A 60-item five-response option objective test (Chemistry achievement test, CAT) developed by the researchers was used as the pretest, post test and retention test. The CAT items which were drawn to cover all the subtopics of thermochemistry on a well planned test blue-print were rearranged with its options in pretest, posttest and retention test to have different numbering so as to give a vague impression that the tests were different. The reliability of CAT was estimated to be 0.81 .Treatment lasted for a period of six weeks. The first author taught the experimental groups while the normal teachers taught the control groups. The data collected with CAT were analyzed using 2x2 factorial ANCOVA with pretest as covariate.

\section{Findings}

Mean, standard deviation and summary of $2 \times 2$ analysis of covariance of effect of treatment and gender on SS2 Chemistry students' academic achievement in Thermochemistry

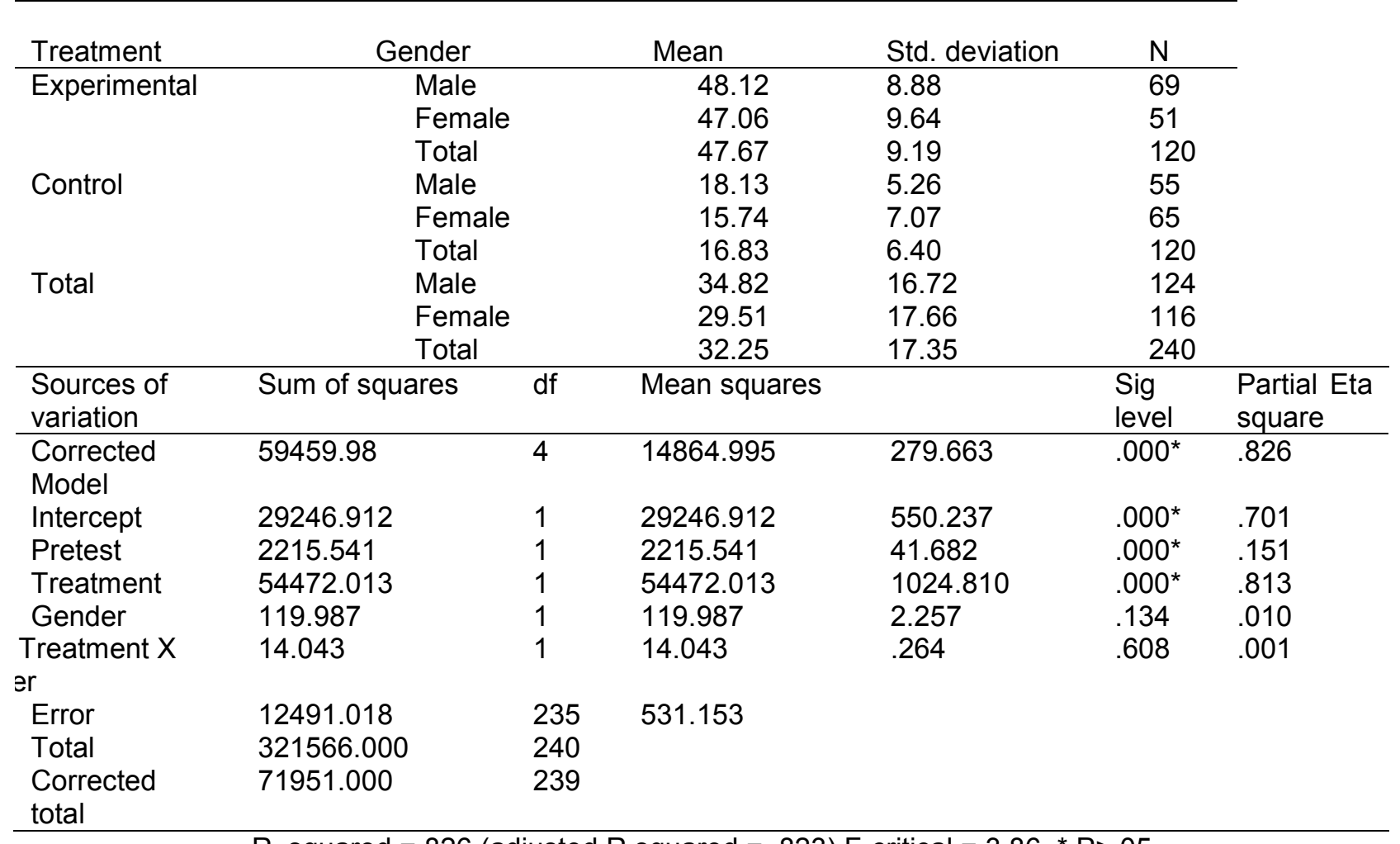

R. squared $=826$ (adjusted R squared $=.823$ ) F-critical $=3.86{ }^{*} \mathrm{P}>.05$ 
The results indicate that, for academic achievement, the main effect for treatment was significant $(F=1024.810, P<.05)$ while the main effects for gender $(F=2.257 ; P>.05)$ and the interaction of treatment and gender $(F=0.264 . P>.05)$ were not significant. These imply that there is no significant difference in the academic performance of male and female SS2 students taught thermochemistry using kitchen resources and those taught without kitchen resources. The eta values obtained indicate that treatment contributed $81.3 \%(.813)$ of the total variance while gender contributed $1.0 \%$ and interaction between gender and treatment contribute $0.1 \%$.

On the other hand, for retention of thermochemistry concepts, the results show that the main effects for treatment was again significant $(F=1473.319 ; \mathrm{p}<.05)$ and the main effects for gender was significant $(F=6.302$; $p<$ .05). Observation shows that male students had a significantly higher mean retention score than their female counterparts. However, the interaction effect of gender and treatment was not significant $(F=2.756 ; p>.05)$. That means there is no significant difference in the mean retention of male and female SS2 students taught thermochemistry using kitchen resources and those taught without kitchen resources. Whereas $86.2 \%$ of the variance of the retention scores was contributed by treatment, gender and interaction effect of gender and treatment contributed $2.6 \%$ and $1.2 \%$ respectively.

\section{CONCLUSION}

The study showed the importance and significant role played by instructional materials (Kitchen resources) on students' achievement, especially in Chemistry. They have positive influence in achievement in Chemistry. This explains why a subject like Chemistry will require real objects and activities/experiment that can convert topics that seem imaginary to concrete for students' understanding. It was therefore observed that using kitchen resources assisted teachers economically and the government in general. It allowed students to interact better in their lesson. It made students to use their intellectual ability during the learning and teaching process. It encouraged creativity, bringing learning homewards and often improved and enhanced students' achievement.

Students in the control groups forgot what they learnt and retained less than students in the experimental group.

\section{RECOMMENDATIONS}

Based on the above findings and conclusions, the following recommendations are made:

1). There is the need for teachers to be resourceful in instructional materials selection and utilization. Thus, regular training and retraining of teachers is hereby recommended.

2). There is also need for the development of positive attitudes by teachers towards the use of kitchen resources for their students. This will encourage the development of their proficiency.

3) Teachers should bring their teaching to the level of the students' aptitude by using familiar instructional resources (kitchen) and make classroom interactions more interesting so as to arouse the interest of the students and academic excellence.

\section{REFERENCES}

Agommo, P. C and Nzewi, U. M., 2004. Effects of videotaped instruction on secondary school students' achievement in physics. Journal of Science Teachers Association of Nigeria, 38 (1 and 2), 88 - 93.

Arowoko, J. G., 2003. Effects of hypotheticodeductive approach on junior secondary 3 students' achievements in integrated science. Journal of Science Teachers Association of Nigeria, 38 (122) $39-45$.

Dahar, M. Aand Faize, F. A.,2011. Effect of the Availability and the Use of Instructional Material on Academic Performance of students in Dunjab (Pakistan). International Journal of Finance and Economics, 11, 1450-2889 (www.eurjournals.com/mefe.htm).

Debacker, T. K and Nelson, R. M., 2000. Motivation to learn science: differences related to gender, class type, and ability. Journal of Educational Research, 93 (4), $245-254$

Ekpo, U. J. 1990. Developing a Science Culture in Nigeria. In D. N. Nwachukwu (ed), 
Development, 174 - 180; Enugu: Sam and Star Group Company. 174 - 180; Enugu: Sam and Star Group Company.

Freier, G. D and Anderson, F. J., 1996.A Demonstration Handbook for Physics. American Association of Physics Teachers New York: Holt Reinhart and Winston.

Johnson, D. W. Roger, T. J and Karl, A. S., 2006.Active Learning: Cooperation in the college classroom, 3rd ed. Edina MN: Interaction Book Company.

Lagoke, B. A.; Jegede, O. J and Oyebanji, P. K., 1997. Towards an Elimination of the Gender Gulfs in Science Concept Attainment through the Use of Environment Analogs: International Journal of Science Education,19(4), 365 -380 .

Lovell, K. and White, G. E., 1995. Some Influences Affecting Choice of Subjects in Schools and Training Colleges. British Journal of Education 16 (7), 25 - 30).

Oladejo, M A; Olosund, G. R. Ojebisi, A. O. and Isola, O. M., 2011. Instructional Materials and Students' Academic Achievement in Physics: some Policy Implications. European Journal of Humanities and Social Sciences 2 (1), 112-126

Onasanya S. A and Omosewo, E. O. 2011., Effect of Improvisation and Standard Instructional Materials on Secondary School Students' Academic Performance in Physics in Illorin, Nigeria. Singapore Journal of Scientific Research, 1, 68-76.

Palinscar, A. 2005. Social Constructionist perspectives on teaching and learning in $\mathrm{H}$. Daniels (ed) An Introduction to Vygotsky. London Routledge.

Rogers, C. 1969.Freedom to learn. Columbs, $\mathrm{OH}$ : Charles Merrill.

Snodgrass, J. B., 2001. From the Kitchen to the Classroom Ideas and Lessons for the Science Teachers. New York: Harper and Row.

Udo, M.E., 2003. The chemistry of corrosion of metals: A resource for effective teaching of redox reaction and electrochemistry. Journal of Science Teachers Association of Nigeria 41 (2) $44-50$.

West African Examinations Council 2010. Chief Examiner's Report. Lagos: WAEC. 